\title{
Принципи диференціальної діагностики гнійно-некротичних процесів діабетичної стопи і сепсису
}

\author{
С. Д. Шаповал, О. В. Трибушний, І. Л. Савон, Л. Ю. Слободченко
}

Інститут сепсису Запорізької медичної академії післядипломної освіти МОЗ України

\section{Principles of differential diagnosis of purulent-necrotic processes of diabetic foot and sepsis}

\author{
S. D. Shapoval, O. V. Trybushnyi, I. L. Savon, L. Yu. Slobodchenko \\ Institute of Sepsis of Zaporizhzhya Medical Academy of Postgraduate Education
}

\begin{abstract}
Реферат
Мета. 3'ясувати діагностичну цінність ранніх маркерів запального процесу в диференціальній діагностиці гнійно-некротичних процесів діабетичної стопи та розвитку сепсису.

Матеріали і методи. Обстежено 989 хворих із ускладненим синдромом діабетичної стопи (СДС), із них у 97 (9,8\%) перебіг захворювання був обтяжений сепсисом.

Результати. За динамікою змін вмісту цитокінів IL-1 $\beta$, IL-6, IL-10, системного цитокіну TNF- $\alpha$, а також C-реактивного білка (СРБ) та прокальцитоніну (ПКТ) у сироватці крові можна диференціювати ускладнений СДС, обтяжений сепсисом. Висновки. Визначення цитокінового статусу, вмісту СРБ, ПКТ має діагностичну цінність в диференціальній діагностиці гнійно-некротичних процесів діабетичної стопи та розвитку сепсису.

Ключові слова: синдром діабетичної стопи; сепсис; цитокіни; гнійно-некротичні процеси.

Abstract

Objective. To assess a diagnostic validity of early markers of inflammatory process in differential diagnosis of purulent-necrotic processes of diabetic foot and development of sepsis.

Materials and methods. There were examined 989 patients, suffering complicated diabetic foot syndrome (DFS), of them in $97(9.8 \%)$ the disease course was complicated by sepsis.

Results. Complicated by sepsis DFS may be differentiated in accordance to the changes in dynamics of contents of cytokines IL-1 $\beta$, IL-6, IL-10, systemic cytokine TNF- $\alpha$, as well as C-reactive protein (CRP) and procalcitonin (PCT) in the blood serum. Conclusion. Determination of the cytokines status, the content of CRP and PCT is diagnostically valuable while accomplishing of differential diagnosis for purulent-necrotic processes of diabetic foot and development of sepsis.

Keywords: diabetic foot syndrome; sepsis; cytokines; purulent-necrotic processes.
\end{abstract}

Сепсис залишається актуальною глобальною медикосоціальною проблемою протягом усього періоду його дослідження. Незважаючи на суттєві досягнення у вивченні біологічної концепції захворювання, поки передчасно говорити про суттеві успіхи в його своєчасній діагностиці і лікуванні [1, 2]. Тривають дискусії щодо дефініцій, діагностики та лікування сепсису, про що свідчать ключові положення рекомендацій Третього міжнародного консенсусу «Визначення сепсису і септичного шоку» («Sepsis-3») [3, 4].

Частота розвитку сепсису у хворих з ускладненим СДС постійно зростає. За різними повідомленнями сепсис розвивається на тлі порушеного вуглеводного обміну у 8 22,7\% пацієнтів [5, 6].

За результатами багатоцентрового дослідження, проведеного в Окленді (США) та базованого на багатомільйонній вибірці хворих, встановлено, що більшість хворих, які помирали, мали клінічно прихований перебіг сепсису, через що показники своєчасної та адекватної лікувальної програми у них значно поступалися показникам у пацієнтів з початково тяжким станом $[7,8]$.

У США сепсис - найчастіша причина смертності; 50\% хворих помирають у відділеннях інтенсивної терапії саме через сепсис, а витрати пацієнтів, які хворіють на сепсис, становлять 22000 доларів. У цілому на боротьбу із сепсисом у США щорічно витрачають 16,7 млрд. доларів [9]. Така незадовільна ситуація зумовлена в тому числі принциповими труднощами своєчасного установлення однозначного діагнозу сепсису.

Відомо, що класичні лабораторні маркери запального процесу мають низьку специфічність та недостатньо надійні для ранньої точної діагностики сепсису. Сучасним мікробіологічним дослідженням властива висока специфічність, але їх загальна чутливість не перевищує 25 $45 \%[10,11]$. Тому нині зусилля всієї медичної спільноти зосереджені на пошуку більш ефективних діагностичних маркерів сепсису.

Мета дослідження: 3'ясувати діагностичну цінність ранніх маркерів запального процесу в диференціальній діагностиці гнійно-некротичних процесів діабетичної стопи та розвитку сепсису.

\section{Матеріали і методи дослідження}

Обстежено 989 хворих із ускладненим СДС, із них у 97 $(9,8 \%)$ захворювання було обтяжене сепсисом. Усі пацієнти перебували на лікуванні в Міському гнійно-септичному центрі з «ліжками діабетичної стопи» Міської клініч- 


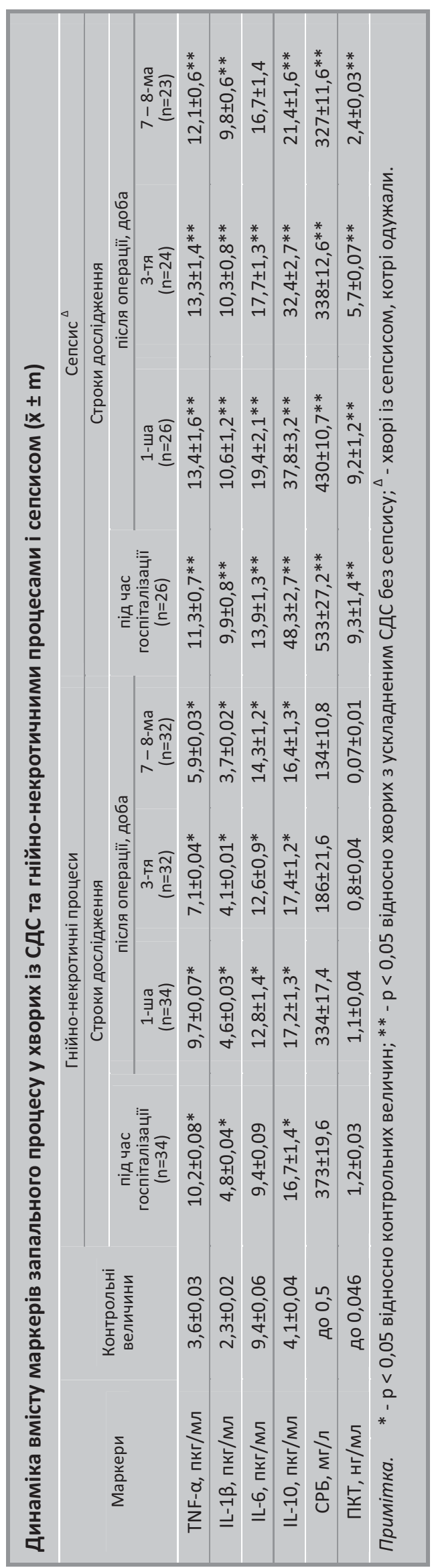

ної лікарні № 3 м. Запоріжжя у 2006 - 2018 рр. Середній вік пацієнтів із ускладненим СДС без сепсису становив $(63,2 \pm 3,2)$ року, із сепсисом - $(62,3 \pm 3,4)$ року. Середня тривалість захворювання на цукровий діабет (ЦД) 2-го типу становила відповідно $(12,2 \pm 3,1)$ та $(12,6 \pm 2,9)$ року.

Серед супутніх захворювань найчастіше констатували ішемічну хворобу серця, гіпертонічну хворобу та ожиріння. У 854 (91,0\%) пацієнтів супутні захворювання були симультанні. За статевими і віковими ознаками, супутньою патологією досліджувані групи пацієнтів репрезентативні.

Причиною сепсису у 87 (89,7\%) пацієнтів була «волога» гангрена нижніх кінцівок. У решти 10 (10,3\%) хворих розвиток сепсису спровокували флегмони та розповсюджений остеоміеліт стопи.

Лікувальна тактика грунтувалася на комплексному підході, включала хірургічне та медикаментозне лікування і відповідала протоколам «SSC-2004», «SSC-2008», «SSC-2012» (до 2016 р.) [10, 11] та рекомендаціям «Sepsis-3» 32016 р. [4, 12].

Оперативні втручання пацієнтам виконували під загальним знеболюванням, останнім часом застосовували подовжену блокаду сідничного нерва.

Оскільки згідно з рекомендаціями «Sepsis-3» термін «тяжкий сепсис» виключено, ретроспективно проаналізовані спостереження, в яких форми сепсису визначали за рекомендаціями Погоджувальної конференції із застосовуванням нового клінічного показника qSOFA (quick SOFA). 3'ясувалося, що в тій чи іншій мірі його застосовували й раніше (середній артеріальний тиск 13,3 кПа (100 мм рт. ст.) і менше, частота дихання 22 за 1 хв і більше). Лишалося тільки уточнити стан пацієнтів за шкалою Глазго. Отже, нам вдалося рандомізувати хворих за формами сепсису. Із 97 хворих із генералізованою інфекцією у 60 діагностовано сепсис, у 37 - септичний шок.

Вміст цитокінів у периферичній крові визначали методом імуноферментного аналізу; СРБ у сироватці крові - класичним біохімічним методом (імунотурбідиметрія) на фотоелектроколориметрі, враховуючи, що нормальні величини СРБ не визначені міжнародними стандартами, а залежать від методик і реактивів; ПКТ - імунолюмінометричним методом за допомогою діагностичного набору «Прокальцитонін - ЛюміТест®» компанії «Брамс - АГ» (Німеччина). Дослідження проводили в динаміці: під час госпіталізації, на 1-шу, 3-тю та 7-му і 8-му добу після операції. Контрольними вважали рівні цитокінів, СРБ, ПКТ, визначені у 18 хворих із ЦД 2-го типу без ускладненого СДС.

Статистичний аналіз проводили з використанням програмного пакета «Stadgraphics Plus for Windows 7,0».

\section{Результати та ї обговорення}

Зміни вмісту цитокінів у периферичній крові хворих із СДС та гнійнонекротичними процесами були подібними. Під час госпіталізації рівні цитокінів IL-1 $\beta$, IL-6, IL-10, а також системного цитокіну TNF- $\alpha$ перевищували контрольні величини відповідно у 2,1; 1,5 - 2; 1,2; 2,8 разу ( $<<0,05)$. У хворих із сепсисом ці зміни були більш вираженими $(\mathrm{p}<0,05)$ (див. таблищю)

У динамиці дослідження вже на 1 -шу та 3 -тю добу після операції вміст цитокінів у хворих без сепсису достовірно зменшувався ( $>$ $0,05)$, чого не спостерігали у хворих із сепсисом. У них, навпаки, рівні IL-1 $1, \mathrm{TNF}-\alpha$ залишалися достовірно вище ( $<<0,05)$, ніж під час госпіталізації, лише вміст IL-10 на 1-шу та 3-тю добу достовірно зменшувався ( $<<0,05)$, але майже у 2 рази перевищував аналогічний показник у хворих із СДС та гнійно-некротичними процесами.

У разі неускладненого перебігу післяопераційного періоду у хворих із СДС без сепсису спостерігали стійку тенденцію до нормалізації рівнів цитокінів $(\mathrm{p}<0,05)$ на відміну від хворих із сепсисом.

Виявлені зміни свідчать про те, що у хворих розвивається запалення, взаємопов'язане з цитокінами імунологічними процесами. Надлишковий синтез IL-1 $\beta$ у хворих із сепсисом може сприяти ін- 
тенсивному зростанню пулу проліферативних клітин, їх диспластичним змінам, прямо пропорційним тяжкості захворювання. Динаміка рівня системного цитокіну TNF- $\alpha$ вказує на важливу роль цитокінових медіаторів у підтримці гомеостазу, а за змінами вмісту IL-10 у сироватці крові можна в деякій мірі прогнозувати тяжкість перебігу захворювання і вибирати тактику лікування. Надлишок цитокінів у хворих з ускладненим СДС свідчить про пригнічення неспецифічного захисту, що може призвести до хронізації процесу.

Незважаючи на те що за вмістом СРБ розпізнають як інфекційні, так і неінфекційні чинники, вивчення динаміки його вмісту у сироватці крові хворих із ускладненим СДС і сепсисом має значний інтерес, оскільки вона відображає зміни тяжкості захворювання. У нашому дослідженні завдання розпізнавання інфекційного чи неінфекційного чинника було спрощене, бо всі хворі мали гнійнонекротичні процеси діабетичної стопи. Маючи власний досвід та спираючись на літературні джерела, пограничним для діагностики інфекційних виразок діабетичної стопи вважали рівень СРБ 320 мг/л.

Під час госпіталізації рівень СРБ у хворих з ускладненим СДС без сепсису коливався в межах 350 - 392 мг/л, тоді як у хворих із сепсисом - 506 - 560 мг/л. Тобто підвищення рівня СРБ понад 500 мг/л опосередковано вказує на можливість генералізації запального процесу. У разі неускладненого перебігу захворювання рівень СРБ прогресивно знижувався вже на 1-шу добу. На 3-тю добу він був більш ніж у 2 рази ( $<0,05)$ менше, ніж під час госпіталізації. На 7 - 8-му добу інфекційного компонента в осередках запалення діабетичної стопи майже не було, а рівень СРБ коливався в межах 133 - 145 мг/л.

У хворих із сепсисом під час госпіталізації рівень СРБ майже у 1,5 разу $(\mathrm{p}<0,05)$ був вище, ніж у хворих без сепсису. У разі виконаного радикального оперативного втручання та вдало підібраної антибактеріальної терапії рівень СРБ на 1-шу та 3-тю добу після операції у цих хворих, як і у хворих без сепсису, прогресивно $(\mathrm{p}<0,05)$ знижувався. Але на 7 - 8-му добу рівень СРБ був значним, і ця обставина залишається нез'ясованою. Адже виконано радикальне оперативне втручання, як правило, «високу» ампутацію 3 приводу «вологої» гангрени нижньої кінцівки, а отже, пусковий чинник сепсису нейтралізовано.

Тест щодо ПКТ був схвалений у 2005 р. керівництвом 3 контролю за харчовими продуктами та лікарськими препаратами США (Food and Drug Administration-FDA) та peкомендований для широкого клінічного застосування. У хворих із системним запаленням бактеріальної етіології ПКТ активується, крім щитоподібної залози, в клітинах ретикуло-ендотеліальної системи, а основними індукторами при цьому є ліполісахарид грамнегативних бактерій, а також прозапальні цитокіни IL-6 та TNF- $\alpha$.

Зміни вмісту ПКТ у хворих з ускладненим СДС у динаміці дослідження перебували у так званій сірій зоні, коли встановити діагноз сепсису з впевненістю неможливо, але вони давали підставу судити про ефективність терапії, яка проводилася.

У хворих із сепсисом під час госпіталізації рівень ПКТ у 7 - 8 разів $(\mathrm{p}<0,05)$ перевищував аналогічний показник у хворих без сепсису. У хворих із сепсисом, які одужали та не мали ускладнень у післяопераційному періоді, вже на 3-тю добу рівень ПКТ був менший майже на 50\% (р < 0,05), ніж під час госпіталізації, а на 7 - 8-му добу - майже в 4 рази ( $<$ 0,05). Це було підгрунтям для корекції моніторингу проведення антибіотикотерапіі та подальшого обгрунтованого лікування.

Тобто визначення вмісту ПКТ дає можливість діагностувати сепсис у ранні строки, судити про перебіг і прогноз захворювання, а також вносити корективи в інтенсивну терапію. Але клініцисти повинні інтерпретувати показники ПКТ з урахуванням клінічного стану хворих, стадії інфекційного захворювання, наявності супутньої патології, адже діагноз «сепсис», встановлений за показниками ПКТ, «за даними науковців з далекого зарубіжжя» може бути помилковим у 25\% хворих.

\section{Висновки}

1. На підставі визначення цитокінового статусу, вмісту СРБ та ПКТ можна проводити диференціальну діагностику гнійно-некротичних процесів діабетичної стопи 3 сепсисом та без нього.

2. Одночасне визначення рівня цитокінів, СРБ, ПКТ дає можливість здійснювати моніторинг тяжкості захворювання, прогнозувати його перебіг та результати лікування.

\section{References}

1. Rudnov VA, Kalabuhov VV. Sepsis i teragnostika. Na puti k personalizirovannoj medicine. Vestn anesteziol i reanimatol. 2015;6:60-7. [In Russian].

2. Byrne L, Van Haren F. Fluid resuscitation in human sepsis: Time to rewrite history? Ann Intensive Care. 2017;7:4. Published online 2017 Yan 3. doi: 10.1186/s13613-016-0231-8.

3. Larichev AB. Snova o sepsise: filosofija dialekticheskogo edinstva definicii i klinicheskoj praktiki . Hirurgia. 2015;(10):84-7. doi: 10.17116/ hirurgia 20151084-87. [In Russian].

4. Singer M, Deutschman CS, Seymour CW. The Third International Consensus Definitions for Sepsis and Septic Shock (Sepsis-3) .YAMA. 2016;315(8):801-10. doi:10.1001/jama.2016.0287.

5. Nelaeva AA, Hasanova JuV,Hobotova ES. Rol provospalitel'nyh citokinov v razvitii i progressirovanii mikro-i makroangiopatij u pacientov s saharnom diabetom 2-go tipa. Angiologija i sosudistaja hirurgija. 2013;19(3):9-12. [In Russian].

6. Marik P, Bellomo R. A rational approach to fluid therapy in sepsis. British Journal of Anaesthosia. 2016;116(3): 339-49. doi:10.1093/bjalaev349.

7. Liesenfeld O, Lehman L, Hunfeld KP, Kost G. Molecular diagnosis of sepsis: New aspects and recent developments Eur. J. Microbiol. Immunol. 2014;4(1):1-25. doi: 10.1556/EuJMI.4.2014.1.1.

8. Park DW, Zmijewski Y. Mitochondrial Dysfunction and Immune Cell Metabolism in Sepsis Infection \&Chemotherapy. 2017;49(1):10-21. doi:10.3947/ic.2017.49.1.10.

9. Chen YX, Li CS. Evaluation of community-acquired sepsis by PIRO system in the emergency department Int. Emerg. Med. 2013;8(6):5217. doi:10/1007/s11739-013-0969-z.

10. Dellinger RP, Levy MM, Rhodes A. Surviving sepsis campaign: international guidelines for management of severe sepsis and septic shock: 2012 Crit. Care Med. 2013 Feb;41(2):580-637. doi:10.1097/ccm. ob013e31827e83af.

11. Levy MM, Dellinger RP, Townsend SR. The Surviving Sepsis Campaign: results of an international guideline-based performance improvement program targeting severe sepsis. Intensive Care Med. 2010 Feb;36(2):222-31. doi:10.1007/s00134-009-1738-3.

12. Rhodes A, Evans LE, Alhazzani W. Surviving Sepsis Campaign: International Guidelines for Management of Sepsis and Septic Shock: 2016 Intensive Care Med. 2017;1-74. doi: 10.1007 / s00134-017-4683-6. 